\title{
ANALISIS KEMAMPUAN MENAFSIRKAN DALAM PEMBELAJARAN FISIKA PESERTA DIDIK KELAS X SMA NEGERI 12 MAKASSAR
}

\author{
Karsimen $^{1)}$, Khaeruddin ${ }^{2)}$, dan Herman) \\ ${ }^{1,2,3)}$ Prodi Pendidikan Fisika, Universitas Negeri Makassar, Indonesia \\ Jl. Daeng Tata Raya, Kampus Parangtambung, 90233 Makassar, Indonesia \\ 1)email: karsimen.ajha@gmail.com
}

\begin{abstract}
Abstrak. Penelitian ini bertujuan untuk mengetahui deskripsi kemampuan menafsirkan dalam pembelajaran fisika peserta didik kelas X SMA Negeri 12 Makassar Tahun Ajaran 2018/2019. Penelitian ini merupakan penelitian survey. Populasi dalam penelitian ini adalah kelas X SMA Negeri 12 Makassar tahun ajaran 2018/2019 dan sampel dipilih secara simple random sampling. Pengambilan data dilakukan dengan menggunakan tes pilihan ganda kemampuan menafsirkan. Data yang terkumpul kemudian dianalisis menggunakan analisis statistik deskriptif. Hasil penelitian yang diperoleh berdasarkan tabel distribusi frekuensi menunjukan dalam pembelajaran fisika secara keseluruhan skor keterampilan proses sains dengan indikator menafsirkan dalam pembelajaran fisika peserta didik sebanyak $0,58 \%$ berada pada kategori sangat rendah; $16,28 \%$ berada pada kategori rendah; $34,88 \%$ berada pada kategori sedang; 9,30\% berada pada kategori tinggi dan 0,58 pada kategori sangat tinggi.
\end{abstract}

Kata kunci: keterampilan proses sains, kemampuan menafsirkan

\begin{abstract}
Analysis Of Interpreting Ability In Physics Learning X Grade Students Sma Negeri 12 Makassar. This aim of this study was to find out interpreting ability in physics learning X grade students of SMA Negeri 12 Makassar academic year 2018/2019 this research was a survey research. The population in this study were class X students of SMA Negeri 12 Makassar academic year 2018/2019 and the sample was selected by using simple random sampling. The data was collected by using multiple choice test of interpreting ability. The collected data was then analyzed using descriptive statistical analysis. The result of this study was obtained from the distribution table which shows the overall scores in the science learning process with indicator students interpreting ability in physics learning process with indicator students interpreting ability in physics as follows, $0,58 \%$ in the very low category; $16,28 \%$ in the low category; 34,88\% in the medium category; $9,30 \%$ in the high category and 0,58\% in the very high category.
\end{abstract}

Keywords: process skills of science, interpreting ability

\section{PENDAHULUAN}

Pendidikan merupakan suatu usaha untuk menumbuhkan dan mengembangkan potensipotensi pembawaan baik jasmani maupun rohani sesuai dengan nilai-nilai yang ada di dalam masyarakat dan kebudayaan. Pendidikan bagi kehidupan umat manusia merupakan kebutuhan mutlak yang harus dipenuhi sepanjang hayat apabila ingin hidup berkembang, sejahtera, dan bahagia sesuai dengan pandangan hidup. Pendidikan menjadi investasi bagi suatu bangsa karena pendidikan akan menentukan kualitas sumber daya manusianya.

Pendidikan merupakan program strategis jangka panjang untuk mengembangkan potensi dalam diri peserta didik agar berdaya guna dalam masyarakat. Sesuai pengertian pendidikan dalam
Undang-Undang Republik Indonesia No. 20 tahun 2003 tentang Sistem Pendidikan Nasional menjelaskan bahwa pendidikan adalah usaha sadar dan terencana untuk mewujudkan suasana belajar dan proses pembelajaran agar peserta didik secara aktif mengembangkan potensi dirinya untuk memiliki kekuatan spiritual keagamaan, pengendalian diri, kepribadian, kecerdasan akhlak mulia, serta keterampilan yang di perlukan dirinya, masyarakat, bangsa dan negara.

Kegiatan belajar merupakan kegiatan seharihari yang penting bagi peserta didik di lingkungan sekolah maupun diluar sekolah. Kegiatan belajar sebagai proses perubahan prilaku manusia melalui latihan atau pengalaman. Orientasi pendidikan sekarang ini biasanya cenderung lebih menitik beratkan pada penguasaan materi saja tanpa 
melihat faktor-faktor lain yang dapat mempengaruhi keberhasilan belajar peserta didik.

Tolak ukur kualitas pendidikan dapat dilihat dari hasil belajar peserta didik selama mengikuti pembelajaran. Hasil belajar mencerminkan sejauh mana peserta didik mengerti, memahami dan mencerna materi pelajaran yang telah dipelajari. Hal yang menarik adalah kenyataan bahwa hasil belajar peserta didik pada mata pelajaran tertentu masih sangat rendah. Terlebih pada mata pelajaran fisika yang mengaitkan antara pengetahuan konkret dan abstrak yang meliputi perhitungan dan kaitannya dengan konsep dan teori-teori fisika.

Kurikulum 2013 (K-13) mengembangkan dua proses pembelajaran yaitu pembelajaran langsung dan pembelajaran tidak langsung. Pembelajaran langsung pada mata pelajaran fisika adalah proses pembelajaran yang mengembangkan pengetahuan, kemampuan berpikir dan keterampilan psikomotorik peserta didik melalui interaksi langsung dengan sumber belajar. Dalam pembelajaran langsung peserta didik melakukan pembelajaran mengamati, menanya, mengumpulkan informasi, mengasosiasi atau menganalisis dan mengomunikasikan apa yang sudah ditemukannya dalam kegiatan analisis.

Salah satu kompetensi inti fisika Sekolah Menengah Atas (SMA) adalah memahami, menerapkan dan menjelaskan pengetahuan faktual, konseptual, prosedural dan metakognitif dalam ilmu pengetahuan, teknologi, seni, budaya dan humaniora dengan wawasan kemanusiaan, kebangsaan, kenegaraan dan peradaban terkait penyebab fenomena dan kejadian, serta menerapkan pengetahuan prosedural pada bidang kajian yang spesifik sesuai bakat dan minatnya untuk memecahkan masalah (Permendikbud No. 69, 2013). Kompetensi ini menjadi dasar untuk mengembangkan pembelajaran fisika di sekolah saat ini.
Pelajaran fisika merupakan salah satu mata pelajaran dalam rumpun sains yang sangat erat kaitannya dengan kehidupan sehari-hari. Secara umum siswa SMA menganggap mata pelajaran fisika merupakan salah satu bidang ilmu pengetahuan alam yang sulit untuk dipahami, sehingga peserta didik kurang berminat untuk mengikuti pelajaran fisika. Pembelajaran fisika seharusnya pembelajaran yang melatih peserta didik untuk mengembangkan keterampilan proses mereka. Pembelajaran sains khususnya fisika merupakan pembelajaran yang berbasis konsep dan keterampilan proses.

Keterampilan proses sains merupakan keseluruhan keterampilan ilmiah yang terarah (baik kognitif maupun psikomotorik) yang dapat digunakan untuk menemukan suatu konsep atau prinsip atau teori, untuk mengembangkan konsep yang telah ada sebelumnya, ataupun untuk melakukan penyangkalan terhadap suatu penemuan/klasifikasi. Dengan kata lain keterampilan ini dapat digunakan sebagai wahana penemuan dan pengembangan konsep yang telah ditemukan atau dikembangkan ini akan memantapkan pemahaman tentang keterampilan proses tersebut.

Salah satu keterampilan proses sains yang harus dikuasai peserta didik ialah kemampuan menafsirkan. Menafsirkan itu penting dalam fisika karena pada materi fisika terdapat grafik dan tabel yang merupakan alat bantu yang digunakan dalam mempresentasikan ide. Grafik dan tabel berperan dalam menggambarkan suatu proses mulai dari konsep yang konkrit dan sederhana seperti posisi benda yang bergerak. Bentuk representasi grafik memiliki hubungan yang tidak terpisahkan dengan konsep. Jadi dalam pembelajaran fisika saat ini guru juga harus menilai keterampilan proses yang dimiliki peserta didik sehingga sesuai dengan tujuan dari pembelajaran sekarang ini. Sehubungan dengan itu, proses pembelajaran dikelas perlu 
dipersiapkan perangkat pembelajaran yang bersifat interaktif, menyenangkan, dan menantang sehingga peserta didik menjadi termotivasi dalam belajar.

Kemampuan menafsirkan merupakan keterampilan proses sains yang sangat penting dalam pembelajaran fisika karena dengan kemampuan menafsirkan ini peserta didik mampu menghubungkan antara variabel-variabel, menemukan pola dan menyimpulkan grafik dengan teori yang sudah diberikan pada saat proses belajar mengajar di sekolah. Kemampuan menafsirkan dalam pembelajaran fisika merupakan keterampilan proses sains yang harus dikuasai oleh peserta didik di sekolah. Hasil yang diperoleh berdasarkan peninjauan dan keterangan guru fisika di SMA Negeri 12 Makassar, bahwa pembelajaran fisika sudah berjalan sesuai dengan rencana pembelajaran yang dibuat di sekolah tersebut namun ada sebagian rencana pembelajaran yang dibuat belum terlaksana dengan baik akibat faktor waktu dan kendala lainnya. Sebagian peserta didik masih kurang dalam kemampuan menafsirkan grafik dan tabel jika materi yang diberikan sulit untuk dipahami pada saat pembelajaran fisika berlangsung, padahal kemampuan menafsirkan merupakan keterampilan proses yang dimiliki oleh setiap peserta didik.

Faktor-faktor yang menyebabkan kurangnya kemampuan menafsirkan peserta didik ini karena peserta didik kurang memperhatikan saat pembahasan materi yang diberikan jika materi tersebut sulit dipahami, selain itu faktor kurangnya minat dalam belajar fisika jika materi yang diberikan sulit dipahami sehingga membuat peserta didik tidak fokus pada saat proses belajar mengajar dan waktu jam pelajaran fisika yang berada pada siang hari sehingga membuat konsentrasi peserta didik sedikit menurun. Dari masalah tersebut peneliti kemudian ingin mengetahui seberapa besar keterampilan proses sains khususnya pada kemampuan menafsirkan peserta didik dalam pembelajaran fisika yang ada di sekolah tersebut untuk materi gerak lurus. Berdasarkan latar belakang inilah, maka peneliti mencoba mengangkat suatu penelitian dengan judul "Analisis Kemampuan Menafsirkan dalam Pembelajaran Fisika Peserta Didik Kelas X SMA Negeri 12 Makassar". Rumusan masalah dalam penelitian ini adalah bagaimana deskripsi kemampuan menafsirkan dalam pembelajaran fisika peserta didik kelas X SMA Negeri 12 Makassar?

\section{METODE}

Penelitian ini merupakan penelitian penelitian survey (Expost facto) yang bersifat deskriptif. Sampel dalam penelitian ini adalah kelas X MIPA SMA Negeri 12 Makassar tahun ajaran 2018/ 2019 jumlah peserta didik masing-masing 106 orang. Instrument penelitian yang digunakan adalah instrumen tes kemampuan menafsirkan dalam pembelajaran fisika dalam bentuk pilihan ganda. Kemampuan menafsirkan yang dimaksud memuat 3 aspek indikator yaitu menghubungkan variabel-variabel, menemukan pola dan menyimpulkan, dengan total soal sebanyak 30 buir soal.

Teknik pengumpulan data yang digunakan dengan memberikan tes kemampuan menafsirkan dalam pembelajaran fisika. Data-data yang diperoleh kemudian dianalisis dengan uji statistik deskriptif.

\section{HASIL DAN PEMBAHASAN \\ HASIL}

Adapun hasil analisis skor untuk setiap aspek indikator menafsirkan dalam pembelajaran fisika peserta didik kelas X SMA Negeri 12 Makassar Tahun Ajaran 2018/2019 
Tabel 1. Analisis skor untuk setiap aspek indikator menafsirkan dalam pembelajaran fisika peserta didik kelas X SMA Negeri 12 Makassar Tahun Ajaran 2018/2019

\begin{tabular}{ccccc}
\hline $\begin{array}{c}\text { Presentase } \\
(\%)\end{array}$ & Interval & Frekuensi & Presentase (\%) & Kategori \\
\hline $81-100$ & $25-30$ & 1 & 0,58 & Sangat Tinggi \\
$61-80$ & $19-24$ & 16 & 9,30 & Tinggi \\
$41-60$ & $13-18$ & 60 & 34,88 & Sedang \\
$21-40$ & $7-12$ & 28 & 16,28 & Rendah \\
$0-20$ & $0-6$ & 1 & 0,58 & Sangat Rendah \\
\hline
\end{tabular}

Tabel 1. Menunjukan bahwa kemampuan menafsirkan dalam pembelajaran fisika peserta didik untuk setiap aspek indikator menafsirkan. Dengan nilai rata-rata yang diperoleh seperti pada tabel 1.
Tabel 2. analisis deskriptif tentang skor kemampuan menafsirkan dalam pembelajaran fisika peserta didik kelas X SMA Negeri 12 Makassar Tahun Ajaran 2018/2019

Tabel 2. analisis deskriptif tentang skor kemampuan menafsirkan dalam pembelajaran fisika peserta didik kelas X SMA Negeri 12 Makassar Tahun Ajaran 2018/2019

\begin{tabular}{ccccc}
\hline No. & Aspek Menafsirkan & $\begin{array}{c}\text { Skor } \\
\text { Maksimum }\end{array}$ & $\begin{array}{c}\text { Rata-Rata } \\
\text { Skor }\end{array}$ & Nilai \\
\hline 1 & $\begin{array}{c}\text { Menghubungkan antara } \\
\text { Variabel }\end{array}$ & 8 & 4,02 & 50,25 \\
2 & Menyimpulkan & 13 & 7,21 & 55,46 \\
3 & Menemukan Pola & 9 & 5,15 & 57,22 \\
\hline
\end{tabular}

Tabel 3. Pengkategorian skor kemampuan menafsirkan dalam pembelajaran fisika peserta didik kelas X SMA Negeri 12 Makassar Tahun Ajaran 2018/2019

\begin{tabular}{clcl}
\hline Parameter & Nilai Parameter & \\
\hline Ukuran Sampel & 106 & \\
Skor Maksimum Ideal & 30 & \\
Skor Minimum Ideal & 0 & \\
Skor maksimum & 25 & \\
Skor minimum & 6 & \\
Skor Rata-Rata & 16,38 & \\
Standar Deviasi & 3,78 & \\
Varians & 14,35 & \\
Gambaran pengategorian skor kemampuan & digambarkan & pada diagram batang sebagai \\
pafsirkan dalam pembelajaran fisika kelas X & berikut: & &
\end{tabular}

SMA Negeri 12 Makassar juga dapat 
Gambar 1. Grafik pengategorian skor kemampuan menafsirkan dalam pembelajaran fisika kelas X SMAN 12 Makassar tahun ajaran 2018/2019

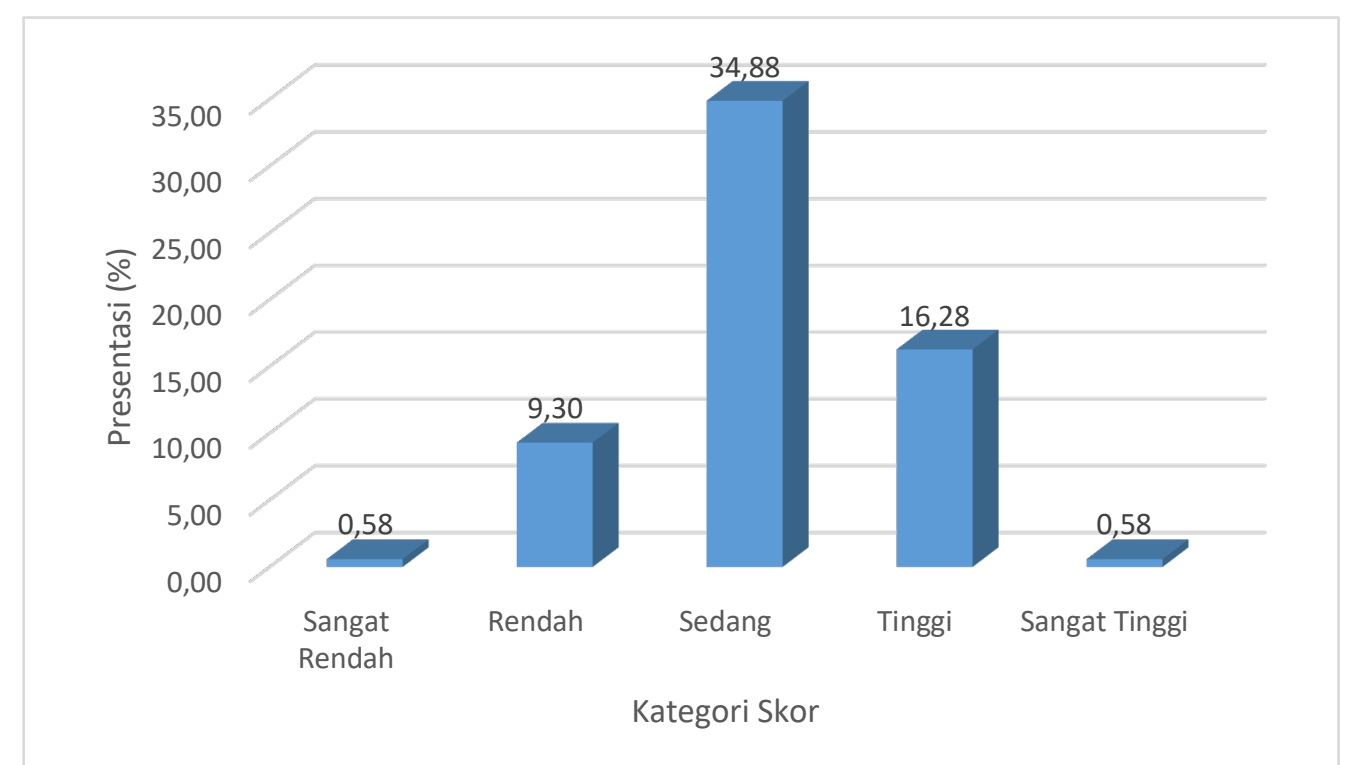

\section{PEMBAHASAN}

Pelaksanaan pembelajaran berbasasis ink Pembahasan hasil penelitian ini akan membahas mengenai keterampilan proses sains fisika dengan indikator menafsirkan peserta didik kelas X SMA Negeri 12 Makassar. Berdasarkan tujuan dari penelitian ini maka akan dibahas tentang deskripsi kemampuan menafsirkan dalam pembelajaran fisika. Hasil analisis data berdasarkan tabel 4.2 menunjukkan bahwa diperoleh skor rata-rata di kelas X SMA Negeri 12 Makassar sebesar 16,38. Pada tabel 4.3 menunjukkan bahwa peserta didik kelas X SMA Negeri 12 Makassar berada pada kategori sedang. Hasil ini menunjukkan bahwa kemampuan menafsirkan peserta didik di sekolah tersebut berada pada kategori sedang.

Kemampuan menafsirkan peserta didik berdasarkan analisis data yang diperoleh berada pada kategori sedang hasil ini menunjukkan bahwa kemampuan peserta didik masih bisa ditingkatkan lagi dan dilatih pada diri peserta didik agar bisa berada pada kategori tinggi dengan menggunakan metode pembelajaran yang sesuai dengan tujuan pendidikan dan kurikulum K13. Kemampaun siswa menafsirkan merupakan salah satu kemampuan dari keterampilan proses sains yang harus dikembangkan dan dilatih pada diri peserta didik. Menurut Harlen dalam Parmolo (1992:45) menyatakan semakin mereka mengulang-ulang materi yang telah diajarkan di sekolah maka kemampuan proses sains mereka akan terlatih.

Kemampuan menafsirkan adalah kemampuan kognitif peserta didik pada level kedua yaitu indikator dari pemahaman. Kemampuan menafsirkan berada pada kategori sedang disebabkan karena rendahnya pengetahuan awal dari peserta didik untuk materi gerak lurus yang masih sangat rendah. Astuti (2015) dalam Parmolo mengatakan kemampuan awal merupakan hasil belajar yang didapat sebelum mendapat kemampuan yang lebih tinggi. Kemampuan awal merupakan prasyarat yang harus dimiliki peserta didik sebelum memasuki pembelajaran materi pelajaran berikutnya yang lebih tinggi. Jadi seseorang peserta didik yang mempunyai kemampuan awal yang baik akan lebih cepat memahami materi dibandingkan dengan peserta didik yang tidak mempunyai kemampuan awal dalam proses pembelajaran. Sebagai contoh untuk setiap aspek indikator menafsirkan berbeda-beda dalam mejawab ada yang lemah pada satu aspek indikator dan ada yang baik dalam menjawab aspek indikator yang 
lain. Hal ini dapat dilihat pada tabel 4.1 setiap indikator memiliki hasil yang berbeda-beda.

Rendahnya kemampuan awal pada setiap aspek indikator menafsirkan disebabkan peserta didik masih menganggap hasil gerakan pada suatu benda hanya bergerak lurus, padahal grafik ada juga yang naik turun, miring dan bergelombang. Faktor lain yang menyebabkan rendahnya kemampuan awal adalah peserta didik belum memahami materi GLB dan GLBB dikarenakan materi gerak lurus kurang menarik dan sulit dipahami sehingga peserta didik bosan dalam mempelajari materi gerak lurus. Informasi ini didapatkan dari hasil wawancara dengan salah satu guru fisika di sekolah tersebut yang mengatakan bahwa banyak siswa yang tidak tertarik dengan belajar fisika karena materinya sulit dipahami karena terlalu banyak persamaanpersamaan dan konsep fisika yang sulit dipahami oleh siswa di sekolah tersebut.

Salmi (2017) berdasarkan penelitian yang didapatkan mengenai kemampuan menafsirkan kemampuan awal memang sangat dibutuhkan dalam proses pembelajaran di kelas sebagai starting point yang akan menimbulkan rasa ingin tahu peserta didik dan pembelajaran berpusat pada peserta didik (student centered learning). Peserta didik dituntut untuk bekerja secara kolaboratif kemudian mengkaji masalah dari fenomena yang sering dijumpai peserta didik dalam kehidupan sehari-hari sehingga peserta didik merasa tertarik untuk mengetahui permasalahan fisika dalam kehidupan sehari-hari dan menutup dengan presentasi produk nyata. Akibatnya peserta didik memiliki gairah atas pelajaran fisika dan mulai terbiasa untuk selalu bertanya bagaimana semua itu terjadi, sehingga mereka mencari tahu jawaban atas pertanyaan-pertanyaan atau masalah dalam proses pembelajarannya.

Keterampilan proses sains fisika untuk indikator menafsirkan memiliki tiga aspek yang digunakan untuk mengukur kemampuan menafsirkan peserta didik yaitu menghubungkan antara variabel-variabel, menemukan pola dan menyimpulkam. Berdasarkan tabel 4.1 diperoleh skor rata-rata dari ketiga aspek menafsirkan untuk aspek menghubungkan variabel-variabel sebesar 4,02 dengan nilai rata-rata 50,52. Nilai rata-rata peserta didik ini masih dibawah nilai KKM sebesar 75 yang ditetapkan di sekolah tersebut. Salah satu penyebab kemampuan peserta didik untuk aspek menghubungkan variabel-variabel dibawah nilai KKM yang ditetapkan di sekolah tersebut adalah pengetahuan awal peserta didik pada aspek tersebut masih sangat rendah dan kurangnya pemahaman konsep yang masih kurang untuk materi gerak lurus.

Analisis aspek menyimpulkan dapat dilihat pada tabel 4.1 menunjukkan nilai rata-rata yang diperoleh peserta didik di sekolah tersebut adalah 55,46 . Hasil ini menunjukkan rata-rata nilai yang diperoleh untuk aspek menghubungkan variabel di sekolah tersebut sebesar 55,46. Nilai rata-rata peserta didik ini masih dibawah nilai KKM sebesar 75 yang ditetapkan di sekolah tersebut. Faktor yang menyebabkan nilai rata-rata dibawah nilai KKM yang ditetapkan di sekolah tersebut karena peserta didik dalam menjawab tes kemampuan menafsirkan dalam pembelajaran fisika untuk aspek menyimpulkan ada yang kurang teliti dan ada juga sebagian yang tidak bisa menghubungkan konsep gerak lurus dengan grafik ketika mengerjakan tes sehingga dalam menjawab soal dengan aspek indikator tersebut sebagian peserta didik ada yang salah menjawab.

Analisis aspek menemukan pola dapat dilihat pada tabel 4.1 menunjukkan nilai rata-rata yang diperoleh peserta didik di sekolah tersebut adalah 57,22 . Hasil ini menunjukkan rata-rata nilai yang diperoleh untuk aspek menyimpulkan di sekolah tersebut sebesar 57,22. Nilai rata-rata peserta didik ini masih dibawah nilai KKM sebesar 75 yang ditetapkan di sekolah tersebut. Faktor yang menyebabkan nilai rata-rata dibawah nilai KKM 
yang ditetapkan di sekolah tersebut karena sebagian peserta didik ada yang menjawab salah pada aspek menemukan pola dikarenakan sebagian peserta didik dalam menemukan pola kemiringan garis benda dipercepat, diperlambat atau percepatanya berubah-ubah kurang dipahami mengenai konsep gerak lurus. Faktor lain yang menyebabkan peserta didik salah menjawab adalah keteledoran dan kurang telitinya peserta didik dalam mengamati grafik gerak lurus pada saat menjawab soal dan terburu-buru pada saat mengerjakan tes yang diberikan.

Salah satu alternatif model pembelajaran yang dapat diterapkan dalam proses pembelajaran fisika adalah model inkuiri terbimbing. Materi yang disajikan guru bukan begitu saja diberikan dan diterima oleh siswa, tapi siswa diusahakan sedemikan rupa sehingga mereka memperoleh berbagai pengalaman dalam rangka menemukan sendiri konsep-konsep yang direncanakan oleh guru (Ahmadi dalam Wahyudin \& Sutikno, 2010). Sedangkan tujuan utama model inkuiri adalah mengembangkan keterampilan intelektual,

\section{REFERENSI}

Deden. 2013. Peningkatan Keterampilan Proses Sains Menggunakan Metode Eksperimen Dalam Pembelajaran IPA Kelas VI SDN 47 Rambin Sanggau. Jurnal Pendidikan dan Penelitian. 4(12), 1-12.

Dimyanti \& Mudjono. 1999. Belajar Dan Pembelajaran. Jakarta: PT Rineka Citra.

Parmolo. 2016. Deskripsi Kemampuan Menafsirkan Grafik Kinematika Siswa Kelas X SMA Negeri Sungai Kakap. Jurnal Ilmiah Pendidikan Fisika, Vol 1 30-31.

Pujianto A., Nurjannah, \& Darmadi L.W. 2013. Analisis Konsepsi Siswa Pada Konsep Kinematika Gerak Lurus. Jurnal Penelitian. Pendidikan Fisika (JPFT), Vol. 1 16-22 berpikir kritis, dan mampu memecahkan masalah secara ilmiah (Dimyati dan Mujiono 1999).

Kemampuan menafsirkan di sekolah ini masuk pada kategori sedang dan untuk nilai rata-rata setiap aspek menafsirkan semuanya dibawah nilai KKM yang ditetapkan di sekolah tersebut. Banyak faktor yang membuat hasil yang diperoleh di sekolah tersebut berada pada kategori sedang salah satunya yaitu karena kemampuan pengetahuan awal peserta didik di sekolah tersebut rendah, kurang telitinya dalam menjawab tes, dan konsep gerak lurus yang belum dipahami dengan baik.

\section{KESIMPULAN}

Kesimpulan yang diperoleh dari hasil penelitian ini yaitu kemampuan menafsirkan dalam pembelajaran fisika peserta didik kelas $\mathrm{X}$ SMA Negeri 12 Makassar tahun ajaran 2018/2019 bahwa kemampuan menafsirkan peserta didik kelas X SMA Negeri 12 Makassar berada pada kategori sedang.

Rusmiyanti, A. 2009. Pendekatan Keterampilan Proses Sains Dengan Menerapkan Model Based Intruction. Jurnal Pendidikan dan Penelitian, Vol 2. 32-36.

Rustaman, NY. 2011. Strategi Belajar Biologi. Bandung: Jurusan Biologi FP MIPA Universitas Pendidikan Indonesia.

Semiawan, C. 1992. Pendekatan Keterampilan Proses. Jakarta: PT Gramedia.

Salmi. 2017. Penerapan Model Pembelajaran Berbasis Proyek Terhadap Motivasi Belajar Fisika dan Keterampilan Proses Sains Peserta Didik SMAN 4 Makassar. Jurnal Sains dan Pendidikan Fisika (JSPF). Vol. 1 238-247

Septi. 2016. Implementasi Pembelajaran IPA Berbasis Pendekatan Keterrampilan Proses Sains Untuk Melatih Keterampilan 
70 Jurnal Sains dan Pendidikan Fisika. Jilid 15, Nomor 3, Desember 2019, hal 63-70

Berfikir Analisis Siswa SMP. Jurnal Ilmiah Pendidikan IPA, Vol 1 21-22.

Tawil. 2014. Keterampilan-Keterampilan Sains Dan Implementasinya Dalam Pembelajaran Fisika. Makassar: Badan Penerbit UNM.
Utami, A.F.R. 2012. Upaya Untuk Meningkatkan Keterampilan Proses Sains Dalam Pembelajaran Fisika Dengan Menerapkan Penerapan Hirarki Inquiri Di Kelas XI 2 IPA. Jurnal Ilmiah Pendidikan Fisika, Vol 2 21-22. 